Original article

\title{
New records of tick-associated spotted fever group Rickettsia in an Amazon- Savannah ecotone, Brazil
}

\author{
A.A.R. Aguirre ${ }^{\mathrm{a}, \mathrm{e}, *}$, Marcos Valério Garcia ${ }^{\mathrm{c}}$, Ivaneide Nunes da Costa ${ }^{\mathrm{b}, \mathrm{d}}$, \\ Bárbara Guimarães Csordas ${ }^{c, e}$, Vinícius da Silva Rodrigues ${ }^{\mathrm{c}}$, Jansen Fernandes Medeiros ${ }^{\mathrm{b}}$, \\ Renato Andreotti ${ }^{\mathrm{c}}$
}

${ }^{a}$ Plataforma de Criação e Experimentação Animal, Fiocruz Rondônia, Oswaldo Cruz Foundation, $n^{\circ}$ 7671, Bairro Lagoa, Porto Velho, RO, CEP 76812-245, Brazil

b Laboratório de Entomologia Médica, Fiocruz Rondônia, Oswaldo Cruz Foundation, Rua da Beira, $n^{\circ}$ 7671, Bairro Lagoa, Porto Velho, RO, CEP 76812-245, Brazil

${ }^{\mathrm{c}}$ Laboratórios de Biologia Molecular e do Carrapato, Brazilian Agricultural Research Corporation, Av. Rádio Maia, n 830, Zona Rural, Campo Grande, MS, CEP 79106550, Brazil

d Programa de Pós-Graduação em Biologia Experimental, Universidade Federal de Rondônia, Rodovia BR 364, Km 9,5, Porto Velho, RO, CEP 76801-059, Brazil

e Programa de Pós-Graduação em Doenças Infecciosas e Parasitárias, Universidade Federal de Mato Grosso do Sul, Av. Costa e Silva, Bairro Universitário, Campo Grande, MS, CEP 79070-900, Brazil

\section{A R T I C L E I N F O}

\section{Keywords:}

Brazilian spotted fever

Rickettsia amblyommatis

Amblyomma oblongoguttatum

Amazon-Savanna ecotone

\begin{abstract}
A B S T R A C T
Human rickettsiosis has been recorded in the Amazon Biome. However, the epidemiological cycle of causative rickettsiae has not been fully accounted for in the Amazon region. This study investigates the presence of spotted fever group (SFG) Rickettsia spp. in free-living unfed ticks of the Amblyomma genus. The study was conducted in seven municipalities in Rondonia State, Brazil, where the main biomes are Amazon forest, Brazilian Savannah and their ecotones (areas of ecological tension between open ombrophilous forest and savannah). The following tick species were collected: Amblyomma cajennense (sensu lato) s.l., A. cajennense (sensu stricto) s.s., A. coelebs, A. naponense, A. oblongoguttatum, A. romitii, A. scalpturatum and A. sculptum. A total of 167 adults, 248 nymphs and 1004 larvae were subjected to DNA extraction and polymerase chain reaction (PCR) to determine the presence of SFG Rickettsia spp. PCR-positive samples included: one A. cajennense s.s. female and one A. cajennense s.l. male from a rural area in Vilhena Municipality; 10 nymphs and a sample of larvae of $A$. cajennense s.l. from a periurban area in Cacoal Municipality; and an A. oblongoguttatum adult male from a rural area of Pimenta Bueno Municipality. All sequences obtained exhibited $100 \%$ identity with Rickettsia amblyommatis sequences. This is the first confirmation of SFG Rickettsia in an A. oblongoguttatum tick. Furthermore, this is the first record of SFG Rickettsia in the municipalities targeted by this study. These results warn that SFG Rickettsia circulation poses a threat in Rondonia State (among Amazon-Savannah ecotones), and that this threat is increased by the fact that SFG Rickettsia infect a human-biting tick species hitherto unconfirmed as a vector.
\end{abstract}

\section{Introduction}

Rickettsia is a genus of bacteria of the order Rickettsiales, $\alpha$ Proteobacteria subgroup. These bacteria are obligate intracellular Gram-negative Coccobacilli (Parola et al., 2005). This genus includes: typhus group (TG), comprised of Rickettsia typhi and R. prowazekii; and spotted fever group (SFG), which includes several species, $R$. rickettsii being the most lethal (Raoult and Roux, 1997; Gillespie et al., 2007; Weinert et al., 2009; Tarragona et al., 2015).

In Brazil, SFG Rickettsia spp. infection is transmitted to humans by ticks. The primary transmission vectors are: Amblyomma sculptum, in the Brazilian Savannah biome; and A. aureolatum, in the Atlantic rainforest biome (Labruna, 2009). SFG Rickettsia spp. have been detected in several species of the Amblyomma genus; some of these species parasitize dogs and humans, and some have already been recorded in Rondonia State (Labruna et al., 2004a,b, 2005a,b, 2007; Barbieri et al., 2008; Szabó et al., 2013; Martins et al., 2014; Oliveira et al., 2016a,b).

The Amblyomma spp. fauna is more diversified in the western Amazon than in other regions of Brazil (Martins et al., 2014). Although many studies of the tick fauna and SFG Rickettsia have been conducted in this region, little is known about the dynamic dispersion of these pathogens and their relation to human illness is poorly understood

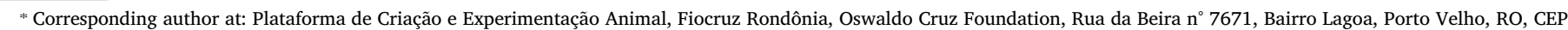
76812-245, Brazil.

E-mail address: andre.aguirre@fiocruz.br (A.A.R. Aguirre). 


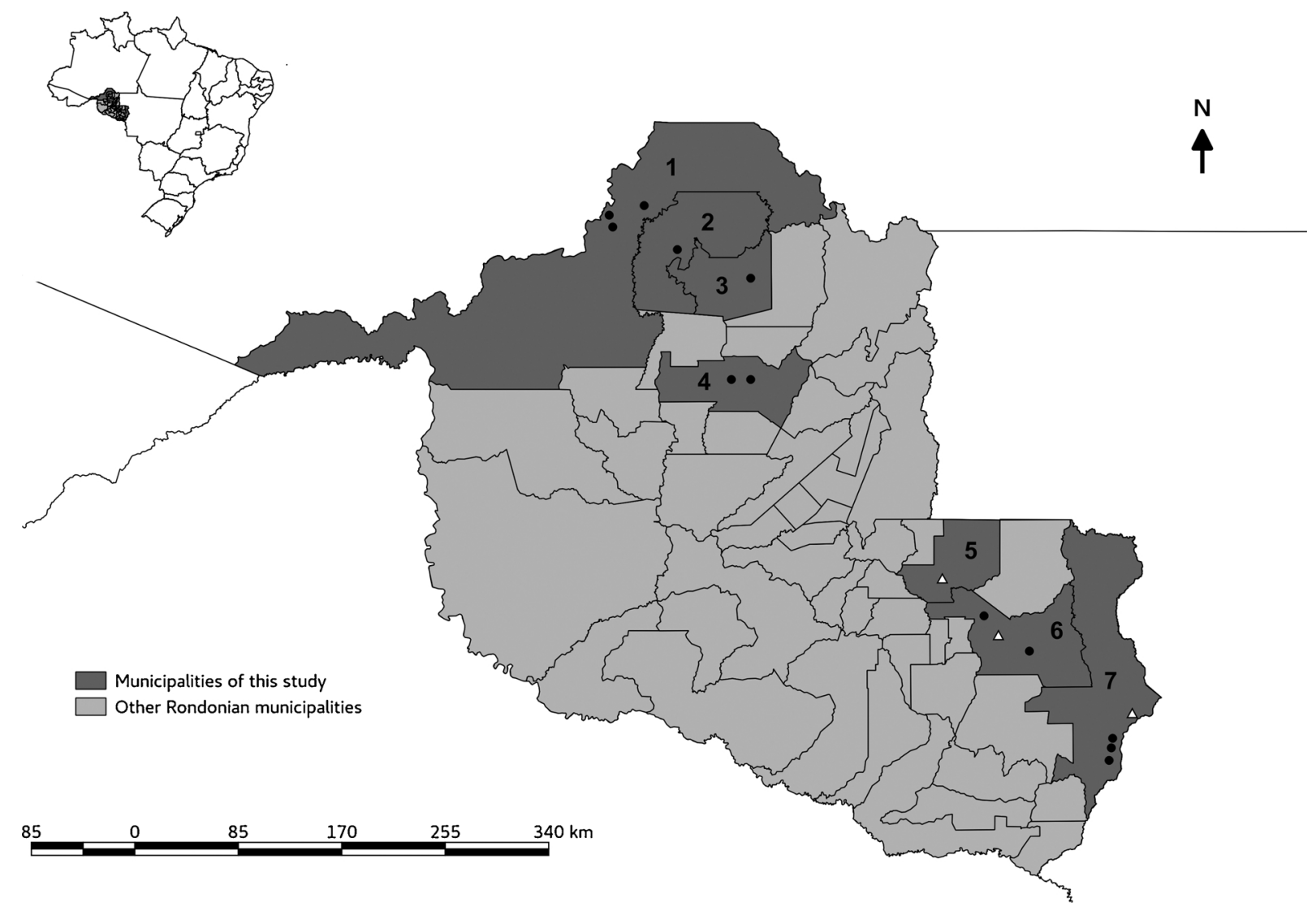

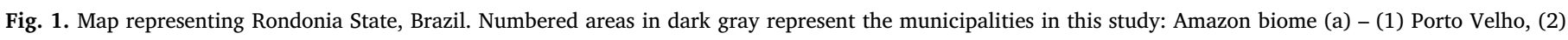

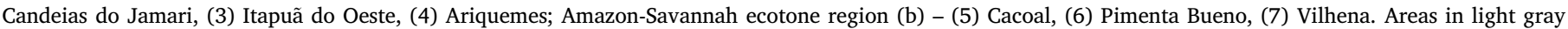

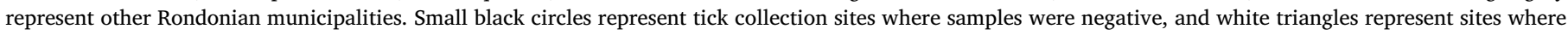
samples were positive and confirmed for Rickettsia amblyommatis.

(Labruna et al., 2004a,b, 2005a,b, 2007; Martins et al., 2014; Oliveira et al., 2016a,b).

Ticks and dogs carrying SFG Rickettsia have been recorded in Rondonia State; this suggests that human infection may be occurring unreported. Brazilian spotted fever (BSF) presents symptoms that are similar to highly prevalent regional illnesses, such as dengue, malaria and leptospirosis, and BSF may therefore be subject to misdiagnosis (Labruna et al., 2004a,b, 2005a,b, 2007). The first confirmed case of BSF in Rondonia State was reported in 2016, by Oliveira et al. (2016a). All these concerns highlight the need for further studies.

This study addresses the potential for the dissemination of tickborne diseases in Rondonia State, as evidenced by the first confirmed case of BSF (Oliveira et al., 2016a), and by several reports of SFG Rickettsia circulation in animals and ixodid vectors (Labruna et al., 2004a,b, 2005a, 2007). The aim of this study was to assess the presence of SFG Rickettsia in ixodid ticks via molecular analysis; samples were collected along animal trails where the likelihood of contact between humans and Amblyomma ticks was high, and collections were performed in two distinct biomes.

\section{Material and methods}

\subsection{Study site}

Tick collections (described below) were performed between April 2015 and December 2016, along animals' trails in forest fragments that provided favorable conditions for the transmission of BSF. Conditions were considered favorable if target locations were close to human shelters (peridomiciles and rural areas), near water sources (streams, brooks, ponds), and likely to be frequented by domestic animals (dogs and horses) and by wild animals (capybaras, tapirs, armadillos and small rodents). Collections were performed in two distinct biomes split between seven municipalities in Rondonia State, Brazil: (a) Amazon rainforest - including the municipalities of Porto Velho $\left(08^{\circ} 45^{\prime} 43^{\prime \prime} \mathrm{S}\right.$, $\left.63^{\circ} 54^{\prime} 14^{\prime \prime} \mathrm{W}\right)$, Candeias do Jamari ( $\left.08^{\circ} 48^{\prime} 35^{\prime \prime} \mathrm{S}, 63^{\circ} 41^{\prime} 44^{\prime \prime} \mathrm{W}\right)$, Itapuã do Oeste $\left(9^{\circ} 11^{\prime} 51^{\prime \prime} \mathrm{S}, 63^{\circ} 9^{\prime} 56^{\prime \prime} \mathrm{W}\right)$ and Ariquemes $\left(9^{\circ} 54^{\prime} 50^{\prime \prime}\right.$ $\mathrm{S}, 63^{\circ} 2^{\prime} 38^{\prime \prime} \mathrm{W}$ ); and (b) Amazon-Savannah ecotone - areas bordering BR-364 road, including the municipalities of Cacoal $\left(11^{\circ} 25^{\prime} 53^{\prime \prime} \mathrm{S}, 61^{\circ}\right.$ $26^{\prime} 52^{\prime \prime}$ W), Pimenta Bueno ( $\left.11^{\circ} 40^{\prime} 29^{\prime \prime} \mathrm{S}, 61^{\circ} 11^{\prime} 28^{\prime \prime} \mathrm{W}\right)$ and Vilhena $\left(12^{\circ} 44^{\prime} 3^{\prime \prime} \mathrm{S}, 60^{\circ} 8^{\prime} 41^{\prime \prime} \mathrm{W}\right)$ (IBGE, 2012) (Fig. 1).

\subsection{Tick collections and identification}

Tick collections were performed using the following methods: $\mathrm{CO}_{2}$ (dry ice) traps; drag flagging; and visual inspection of vegetation up to one meter beyond the edge of animal trails (Oliveira et al., 2000; Castro and Clover, 2010). Collected unfed ticks were taken to the laboratory alive. Adults and nymphs were identified taxonomically under a stereoscopic microscope (Barros-Battesti et al., 2006; Martins et al., 2010). Identification was verified for $A$. cajennense (sensu stricto) (s.s.) and $A$. sculptum females (both from the A. cajennense complex) according to Nava et al. (2014); each species exhibited clear differences on the genital aperture (Soares et al., 2015). Males and nymphs from the $A$. cajennense complex were identified as A. cajennense (sensu lato) s.l. The genus of larvae collected in bunches was identified morphologically (Barros-Battesti et al., 2006), and a portion of the larvae was allocated to feed on rabbits (Bechara et al., 1995) with the aim of producing nymphs for species identification (Martins et al., 2010). Following identification, ticks were preserved in absolute ethanol at $-18^{\circ} \mathrm{C}$ until DNA extraction and polymerase chain reaction (PCR). All procedures 
with animals were carried out according to ARRIVE guidelines and in accordance with the U.K. Animals (Scientific Procedures) Act, 1986 and associated guidelines, EU Directive 2010/63/EU for animal experiments, and the Ethics Commission on the Use of Animals/CEUA of Fiocruz Rondônia, under protocol number 2015/18, approved this study.

\subsection{DNA extraction, $P C R$ and sequencing analysis}

DNA was extracted from all samples and molecular analysis was performed using PCR. The presence of SFG Rickettsia was tested via amplification of the ompA gene fragment. Extractions were performed individually for adults, in pools of up to 10 specimens for nymphs, and in pools of bunches for larvae, following the guanidine isothiocyanatephenol technique, as previously described by Sangioni et al. (2005). The obtained DNA was amplified using the primers Rr190.70p and Rr190.602n to amplify a 532-pb fragment of the ompA gene, present exclusively in only SFG Rickettsia (Regnery et al., 1991).

DNA from positive samples was purified using Purelink ${ }^{\mathrm{TM}}$ PCR Purification Kit (Invitrogen, CA, USA). Further sequencing was performed with the Sequencing and Genotyping DNA Platform in René Rachou Research Center, Oswaldo Cruz Foundation, Belo Horizonte, Brazil. The Sanger method (Sanger et al., 1977) was used in an ABI 3730 (Life Technologies) sequencer, and samples were sequenced in duplicate. Sequences were then aligned with CulstalW algorithm using the MEGA 7.0 program (Kumar et al., 2016). Sequences were deposited in GenBank, with major identity criteria determined by the BLASTn search tool.

The evolutionary history was inferred by using the Maximum Likelihood method based on the Tamura 3-parameter model (Tamura, 1992) for phylogenetic tree analysis. Initial trees for the heuristic search were obtained automatically by applying Neighbor-Join and BioNJ algorithms to a matrix of pairwise distances estimated using the Maximum Composite Likelihood (MCL) approach, and then selecting the topology with superior log likelihood value. A discrete Gamma distribution was used to model evolutionary rate differences among sites ( 5 categories $(+\mathrm{G}$, parameter $=0,6801)$ ). The tree was drawn to scale, with branch lengths measured in the number of substitutions per site. The proportion of sites where at least one unambiguous base is present in at least one sequence for each descendant clade is shown next to each internal node in the tree. The analysis involved 38 nucleotide sequences. Codon positions included were $1^{\circ}+2^{\circ}+3^{\circ}+$ Noncoding. All positions containing gaps and missing data were eliminated. Evolutionary analyses were conducted in MEGA7 program (Kumar et al., 2016).

\section{Results}

A total of 1420 unfed Amblyomma ticks was collected in this study. Of these, 178 were obtained from (a) region (Amazon biome) (4 larvae, 132 nymphs and 42 adults), and 1242 were obtained from (b) region (Amazon-Savannah ecotone) (1000 larvae, 117 nymphs and 125 adults). Table 1 shows the total number of ticks, life stages and species, and the results of SFG Rickettsia detection with respect to the relevant biomes and municipalities. Nine species were identified: $A$. cajennense s.l. (1173, including a bunch of 1000 larvae), A. oblongoguttatum (98), A. naponense (59), A. cajennense s.s. (43), A. coelebs (13), A. scalpturatum (13), A. sculptum (7), A. ovale (5), A. romitii (4), A. calcaratum (1), and Amblyomma spp. larvae (4). Additionally, four A. oblongoguttatum and four $A$. ovale adults (two males and two females each) were collected from a domestic dog in a rural area in Candeias do Jamari Municipality (data not shown).

Nine samples were PCR-positive, all from free-living ticks: two $A$. oblongoguttatum females from Candeias do Jamari Municipality; one A. oblongoguttatum male from Pimenta Bueno Municipality; one A. cajennense s.l. male and one A. cajennense s.s. female from Vilhena Municipality; three nymph pools containing 10 specimens each, and a bunch of 1000 larvae of $A$. cajennense s.l. from Cacoal Municipality. Nevertheless, from the nine samples PCR-positive, four were inadequate for sequencing due to low quality of DNA, and only five samples shared sequence homology with ompA sequences on GenBank. All five of these samples exhibited $100 \%$ identity with a Rickettsia amblyommatis sequence, An 13 isolate (GenBank: CP015012), as determined by BLASTn program analysis. Furthermore, all five samples exhibited $100 \%$ identity with more than 10 sequences from several "Candidatus Rickettsia amblyommii" records, and 99\% identity with the "ARANHA" strain (GenBank AY360213), which has been recorded near the regions targeted by this study. The identity of $R$. amblyommatis was determined by phylogenetic analysis of ompA sequences (access numbers GenBank MF188911, MF188912, MF188913, MF188914) (Fig. 2).

\section{Discussion}

This is the first study to report the presence of SFG Rickettsia in a specimen of $A$. oblongoguttatum tick in South America. The specimen was collected in an Amazon-Savannah ecotone (IBGE, 2012), in Pimenta Bueno Municipality, Rondonia, Brazil. This is the first record of A. oblongoguttatum carrying SFG Rickettsia ompA already confirmed by $100 \%$ sequence identity. An earlier detection of SFG Rickettsia in A. oblongoguttatum was reported in Panama (Central America), but the authors of that study emphasized that the speciation analysis could not be completed due to a low number of DNA copies (Bermúdez et al., 2009). In addition, two specimens of $A$. oblongoguttatum from Candeias do Jamari Municipality tested positive for SFG Rickettsia; however, the species could not be confirmed by sequencing due most likely to low DNA integrity.

One larval and one nymphal DNA sample of $A$. cajennense s.l. from Cacoal Municipality, and an A. cajennense s.l. male and an A. cajennense s.s. female from Vilhena Municipality exhibited $100 \%$ sequence identity with $R$. amblyommatis ompA (along with other "Candidatus R. amblyommii" strains). Thus, this study is also the first confirmed record of $R$. amblyommatis in A. cajennense s.s., in Rondonia State (an adult female from Vilhena Municipality).

It is worth mentioning that $A$. cajennense s.s. belongs to a namesake complex which encompasses six species (including A. sculptum) (Nava et al., 2014), and that the last SFG Rickettsia report of this complex in Rondonia was made a decade before the complex was first described (Labruna et al., 2004b). Since there have also been reports in Rondonia State of A. sculptum (in Pimenta Bueno Municipality), records made prior to the complex description tend to be treated as A. cajennense s.l.

In this study, $A$. cajennense s.s. was identified in the municipalities of Cacoal, Pimenta Bueno, and Vilhena, which accords with previous reports (Martins et al., 2016). This indicates that the enzootic cycle and circulation of $R$. amblyommatis is complex, and may involve several tick vectors and potentially utilize several animal species as natural reservoirs. Aside from the records cited, the presence of $R$. amblyommatis is unprecedented in the municipalities of Rondonia that were the focus of this study.

Recently, "Candidatus R. amblyommii" was formally named R. amblyommatis sp. nov., according to the International Code of Nomenclature of Prokaryotes (Karpathy et al., 2016). The tick species most commonly infected by this pathogen is A. americanum, which has a rate of infection above 40\% in North America (Burgdorfer et al., 1981; Karpathy et al., 2016). However, this pathogen has also been found in several Central and South American countries, where it infects many other Amblyomma species (Sánchez-Montes et al., 2016). In Brazil, this bacteria has already been detected in A. auricularium, A. cajennense s.s., A. coelebs, A. geayi, A. humerale, A. longirostre, A. parkeri and A. 


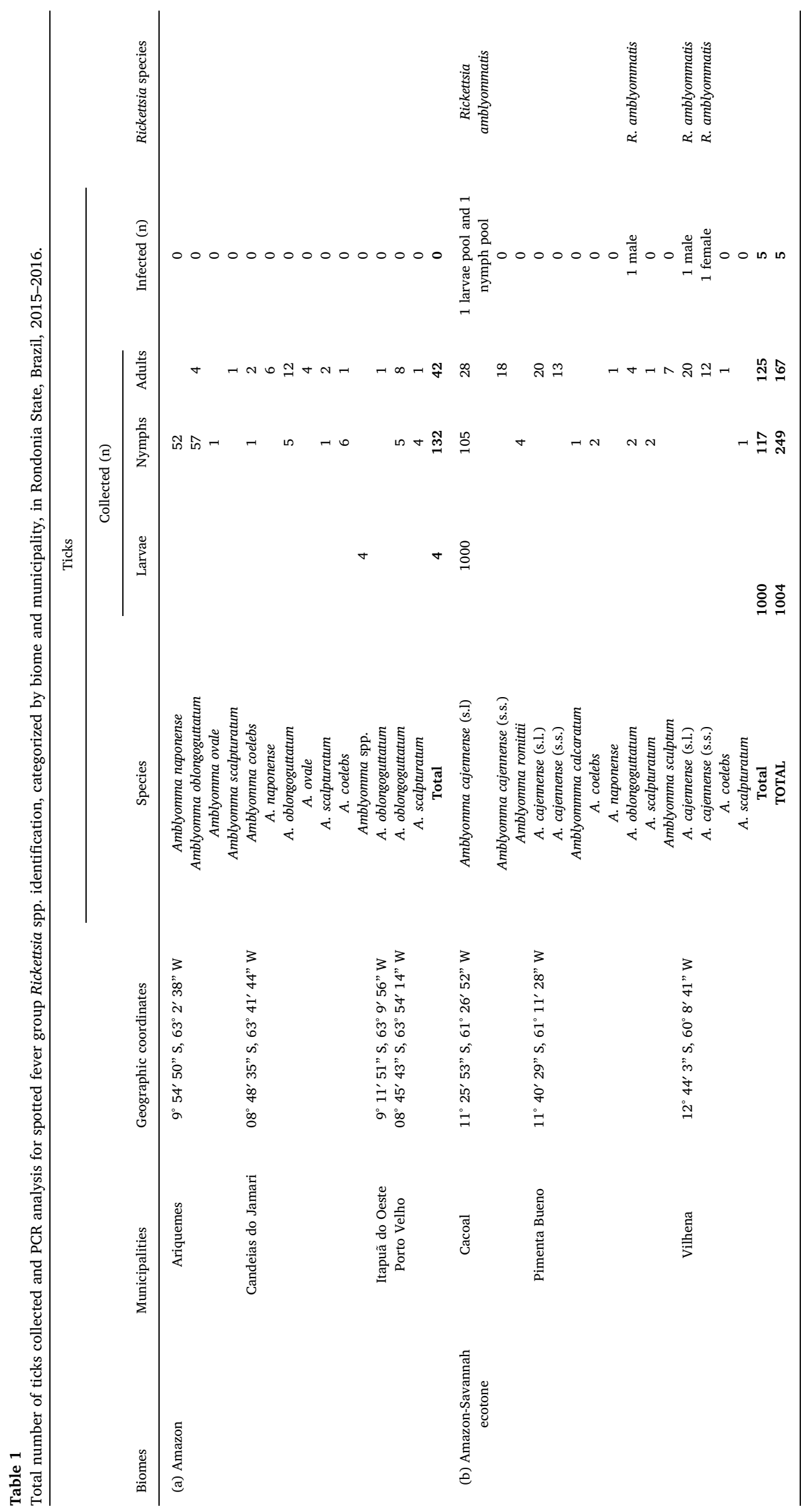




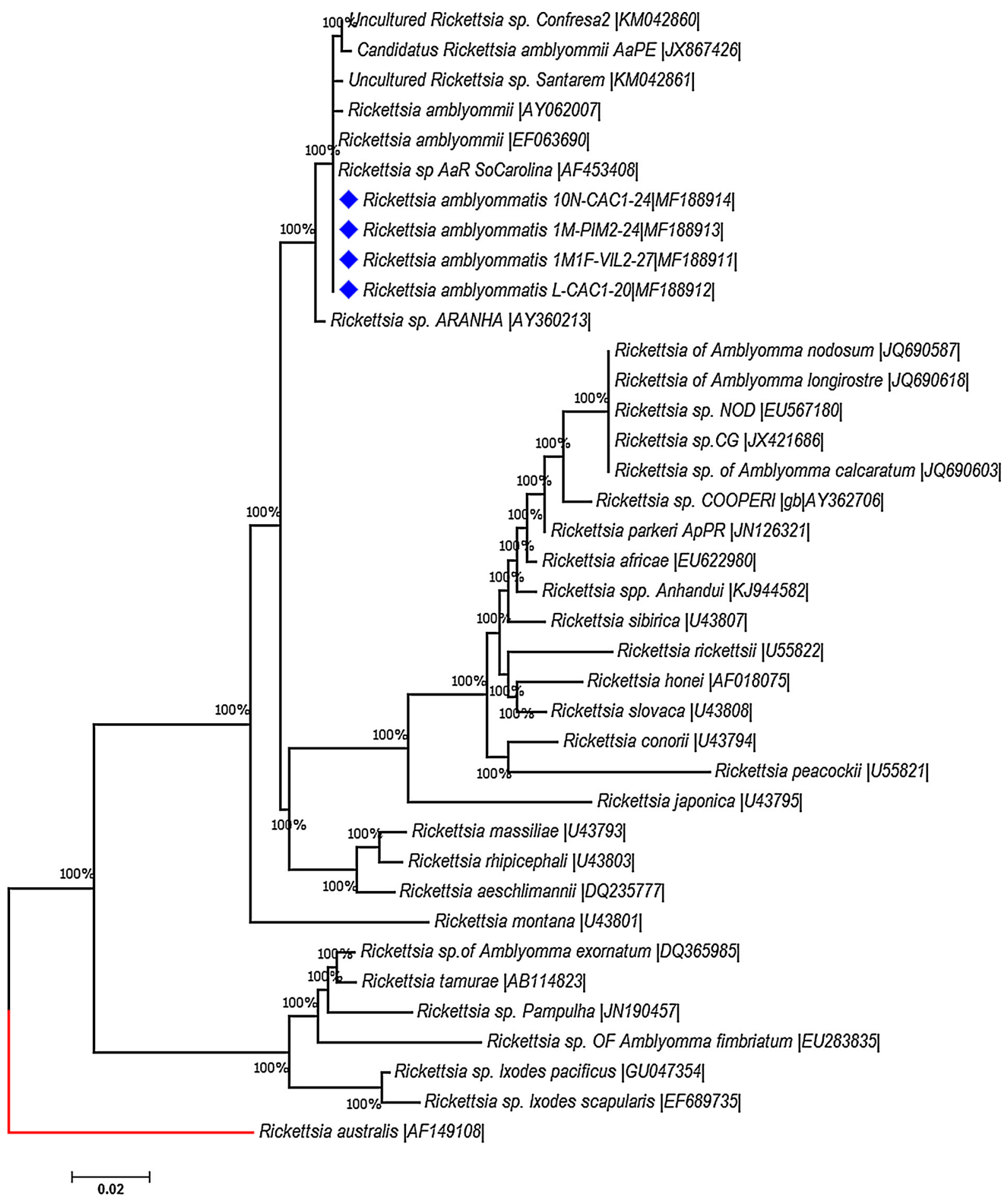

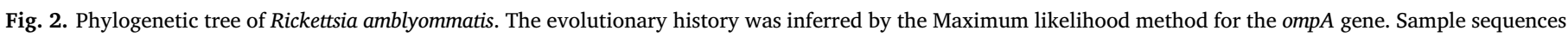

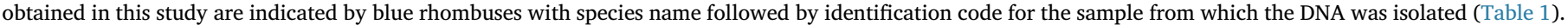
(For interpretation of the references to colour in this figure legend, the reader is referred to the web version of this article.)

sculptum, and has been recorded in the states of Bahia, Mato Grosso, Pará, Paraná, Pernambuco, Rondônia and São Paulo (Labruna et al., 2004a,b; Ogrzewalska et al., 2008, 2010, 2011; Pacheco et al., 2012; Saraiva et al., 2013; Alves et al., 2014; Lopes et al., 2014; Soares et al., 2015).

BLAST analysis of all positive samples exhibited $100 \%$ identity with: the An13 isolate of $R$. amblyommatis; "Candidatus R. amblyommii" isolates 11-TC-1-1, GP4A, AcCR and TX116, and other rickettsiae isolates from North and Central America, including isolates that have been related to human pathogens by Billeter et al. (2007), (GenBank: EF063690); and with the AcaIII isolate of "Candidatus R. amblyommii" from the municipalities of Governador Jorge Teixeira and Monte Negro, Rondonia, an isolate that was not deposited on GenBank because it exhibited 100\% identity with ArR/SoCarolina (GenBank: AF453408), according to Labruna et al. (2004b). The sequences reported here exhibited $99 \%$ identity with sequences from other studies conducted in Brazil, including: Ariquemes (RO), "ARANHA" strain (GenBank: AY360213), Confresa (MT), Confresa2 clone (GenBank: KM042860), 
Ibimirim (PE), AaPE strain (GenBank: JX867426) and Santarém (PA), Santarem clone (GenBank: KM042861) (Labruna et al., 2004a; Saraiva et al., 2013; Soares et al., 2015).

Since the discovery of $R$. amblyommatis, its pathogenesis in humans has remained unclear. Laboratory assays with experimentally infected animals did not elicit evident clinical signs. In the same study, the authors evaluated humans in a region with high rates of tick-borne infection and constant exposure to A. americanum parasitism, yet no relevant clinical signs were detected (Burgdorfer et al., 1981). Nevertheless, recent reports suggest that some correlation exists between mild illness and rickettsiosis in people that test seropositive for $R$. amblyommatis and have had previous contact with $A$. americanum (Apperson et al., 2008; Delisle et al., 2016).

In Rondonia State, Rickettsia genera were described for the first time in Ariquemes Municipality, where A. longirostre was infected by the "ARANHA" strain (AY360213) (Labruna et al., 2004a). Shortly thereafter, a strain $100 \%$ identical to ArR/SoCarolina (AF453408) was detected infecting $26.8 \%$ of $A$. cajennense s.l. (collected from Governador Jorge Teixeira Municipality) and $14.3 \%$ of A. coelebs (collected from Monte Negro Municipality) (Labruna et al., 2004b). In Monte Negro, $11.6 \%$ of dogs from rural areas and $3.9 \%$ of dogs from urban areas tested seropositive for at least one of three Rickettsia species: $R$. parkeri; $R$. amblyommatis and $R$. rhipicephali (Labruna et al., 2007). After these studies were conducted, Rickettsia was not reported in Rondonia State until the first confirmed case of BSF in Ariquemes Municipality (Oliveira et al., 2016a,b). These authors had already confirmed Rickettsia spp. in Dermacentor nitens, Rhipicephalus sanguineus sensu lato and $R$. microplus, in Rondonia State. However, these authors did not identify the species of Rickettsia in the human case of BSF, nor did they identify the species of Rickettsia infecting the three types of tick. It is worth noting that up to now there has been no record of $A$. cajennense complex in Ariquemes Municipality, which suggests that other tick species are involved in the transmission cycle.

While performing collections, the authors of this study found $A$. oblongoguttatum and $A$. ovale parasitizing a dog in Candeias do Jamari Municipality. According to the literature, dogs may be accidental hosts for these ticks even though adult ticks normally parasitize wild carnivores (Labruna et al., 2000). Furthermore, dogs play an important role in the zoonotic cycle of rickettsiosis: dogs can serve as an amplifier host to several SFG Rickettsia spp. by transmitting ticks between wild animals and also by transmitting ticks from wild animals to humans (Labruna et al., 2007; Melo et al., 2011).

A. oblongoguttatum has been reported parasitizing humans in Brazil, mainly in Amazon forest areas (including in Rondonia State), and there have been additional reports in the South Region of Brazil, as well as in neighboring countries (Labruna et al., 2000, 2005b; Arzua et al., 2005; Guglielmone et al., 2006). A. oblongoguttatum is very common in the region studied. Now that we have confirmed $A$. oblongoguttatum as a potential vector of SFG Rickettsia, local public health authorities should be altered and systems for the control and surveillance of zoonotic diseases should include this tick as a species of concern.

Dogs are viable hosts for A. oblongoguttatum and humans are frequently bitten by this tick species (Labruna et al., 2000; Guglielmone et al., 2006; Martins et al., 2017), and SFG Rickettsia infection has been reported in both dogs and humans in the region studied. Given these facts, we would like to reiterate the strong possibility that the $A$. oblongoguttatum is involved in the zoonotic transmission cycle of BSF, and that this vector may pose a threat especially in areas where the $A$. $c a$ jennense complex has not been reported. Knowledge of this possible threat and the new records of SFG Rickettsia in Rondonia add information of great value to our limited understanding of the circulation dynamics of rickettsiosis in animals, ixodid vectors and humans, especially with respect to the Amazon region.

\section{Acknowledgements}

We wish to thank CAPES, CNPq, FAPERO and Fundect for financial support, and we wish to thank the sequencing service of Sequencing and Genotyping DNA Platform in René Rachou Research Center, Oswaldo Cruz Foundation, Belo Horizonte, Brazil.

\section{References}

Alves, A.S., Melo, A.L.T., Amorim, M.V., Borges, A.M.C.M., Silva, L.G., Marins, T.F., Labruna, M.B., Aguiar, D.M., Pacheco, R.C., 2014. Seroprevalence of Rickettsia spp. in equids and molecular detection of 'Candidatus rickettsia amblyommii' in Amblyomma cajennense sensu lato ticks from the pantanal region of mato grosso, Brazil. Brazil. J. Med. 1242-1247. http://dx.doi.org/10.1603/ME14042.

Apperson, C.S., Engber, B., Nicholson, W.L., Mead, D.G., Engel, J., Yabsley, M.J., Dail, K., Johnson, J., Watson, D.W., 2008. Tick-Borne diseases in North Carolina: is Rickettsia amblyommii a possible cause of rickettsiosis reported as rocky mountain spotted fever? Vector-Borne Zoonotic Dis. 8, 597-606. http://dx.doi.org/10.1089/vbz.2007. 0271.

Arzua, M., Onofrio, V.C., Barros-Battesti, D.M., 2005. Catalogue of the tick collection (Acari, Ixodida) of the Museu de Historia Natural Capao da Imbuia, Curitiba, Parana. Brazil. Rev. Bras. Zool. 22, 623-632. http://dx.doi.org/10.1590/S0101 81752005000300015.

Barbieri, F.S., Brito, L.G., Labruna, M.B., Barros-Battesti, D.M., Camargo, L.M.A., Famadas, K.M., 2008. Description of the larva of Amblyomma ovale Koch, 1844 (Acari: Ixodidae) by light and scanning electron microscopy. Syst. Appl. Acarol. 13, 109. http://dx.doi.org/10.11158/saa.13.2.3.

Barros-Battesti, D.M., Arzua, M., Bechara, G.H., 2006. Carrapatos de importância médicoveterinária da Região Neotropical: um guia ilustrado para identificação de espécies.

Bechara, G.H., Szabó, M.P.J., Ferreira, B.R., Garcia, M.V., 1995. Rhipicephalus sanguineus tick in Brazil: feeding and reproductive aspects. Braz. J. Parasitol. Vet. 4 (2), 61-66.

Bermúdez, S.E., Eremeeva, M.E., Karpathy, S.E., Samudio, F., Zambrano, M.L., Zaldivar, Y., Motta, J.A., Dasch, G.A., 2009. Detection and identification of rickettsial agents in ticks from domestic mammals in Eastern Panama. J. Med. Entomol. 46, 856-861. http://dx.doi.org/10.1603/033.046.0417.

Billeter, S.A., Blanton, H.L., Little, S.E., Levy, M.G., Breitschwerdt, E.B., 2007. Detection of Rickettsia amblyommii in association with a tick bite rash. Vector Borne Zoonotic Dis. 7 (4), 607-610.

Burgdorfer, W., Hayes, S.F., Thomas, L., 1981. A new spotted fever group rickettsia from the lone star tick. In: Anacker, R.W. (Ed.), Rickettsiae and Rickettsial Diseases. Academic Press, New York, pp. 213-267.

Castro, M.B., Clover, J.R., 2010. A comparison of visual and flagging methods for estimating adult Ixodes pacificus (Acari: Ixodidae) tick abundance. J. Vector Ecol. 35, 435-438. http://dx.doi.org/10.1111/j.1948-7134.2010.00104.x.

Delisle, J., Mendell, N.L., Stull-Lane, A., Bloch, K.C., Bouyer, D.H., Moncayo, A.C., 2016. Human infections by multiple spotted fever group Rickettsiae in Tennessee. Am. J. Trop. Med. Hyg. 94, 1212-1217. http://dx.doi.org/10.4269/ajtmh.15-0372.

Gillespie, J.J., Beier, M.S., Rahman, M.S., Ammerman, N.C., Shallom, J.M., Purkayastha, A., Sobral, B.S., Azad, A.F., 2007. Plasmids and Rickettsial evolution: insight from Rickettsia felis. PLoS One 2. http://dx.doi.org/10.1371/journal.pone.0000266.

Guglielmone, A.A., Beati, L., Barros-Battesti, D.M., Labruna, M.B., Nava, S., Venzal, J.M., Mangold, A.J., Szabó, M.P.J., Martins, J.R., González-Acuña, D., Estrada-Peña, A., 2006. Ticks (Ixodidae) on humans in south america. Exp. Appl. Acarol. 40, 83-100. http://dx.doi.org/10.1007/s10493-006-9027-0.

Instituto Brasileiro de Geografia e Estatística - IBGE, 2012. Manual Técnico da Vegetação Brasileira, Rio de Janeiro.

Karpathy, S.E., Slater, K.S., Goldsmith, C.S., Nicholson, W.L., Paddock, C.D., 2016. Rickettsia amblyommatis sp. Nov., a spotted fever group Rickettsia associated with multiple species of Amblyomma ticks in noRth, Central and South America. Int. J. Syst. Evol. Microbiol. 66, 5236-5243. http://dx.doi.org/10.1099/ijsem.0.001502.

Kumar, S., Stecher, G., Tamura, K., 2016. MEGA7: molecular evolutionary genetics analysis version 7.0 for bigger datasets. Mol. Biol. Evol. 33, 1870-1874. http://dx. doi.org/10.1093/molbev/msw054.

Labruna, M.B., Homem, V.S.F., Heinemann, M.B., Neto, J.S.F., 2000. Ticks (Acari: Ixodidae) associated with rural dogs in Uruará, Eastern Amazon, Brazil ticks (Acari: Ixodidae) associated with rural dogs in Uruara Eastern Amazon. Brazil. J. Med. Entomol. 37, 774-776. http://dx.doi.org/10.1603/0022-2585-37.5.774.

Labruna, M.B., McBride, J.W., Bouyer, D.H., Camargo, L.M.a., Camargo, E.P., Walker, D.H., 2004a. Molecular evidence for a spotted fever group Rickettsia species in the tick Amblyomma longirostre in Brazil. J. Med. Entomol. 41, 533-537. http://dx.doi. org/10.1603/0022-2585-41.3.533.

Labruna, M.B., Whitworth, T., Bouyer, D.H., McBride, J., Camargo, L.M.A., Camargo, E.P., Popov, V., Walker, D.H., 2004b. Rickettsia bellii and Rickettsia amblyommii in Amblyomma ticks from the State of Rondônia, Western Amazon, Brazil. J. Med. Entomol. 41, 1073-1081. http://dx.doi.org/10.1603/0022-2585-41.6.1073.

Labruna, M.B., Camargo, L.M.A., Camargo, E.P., Walker, D.H., 2005a. Detection of a spotted fever group Rickettsia in the tick Haemaphysalis juxtakochi in Rondonia. Brazil. Vet. Parasitol. 127, 169-174. http://dx.doi.org/10.1016/j.vetpar.2004.09. 024.

Labruna, M.B., Camargo, L.M.A., Terrassini, F.A., Ferreira, F., Schumaker, T.T.S., Camargo, E.P., 2005b. Ticks (Acari: Ixodidae) from the state of Rondônia, western Amazon, Brazil. Syst. Appl. Acarol. 10, 17-32.

Labruna, M.B., Horta, M.C., Aguiar, D.M., Cavalcante, G.T., Pinter, A., Gennari, S.M., 
Camargo, L.M.A., 2007. Prevalence of Rickettsia infection in dogs from the urban and rural areas of Monte Negro Municipality, Western Amazon, Brazil. Vector-Borne Zoonotic Dis. 7, 249-255. http://dx.doi.org/10.1089/vbz.2006.0621.

Labruna, M.B., 2009. Ecology of rickettsia in South America. Ann. N. Y. Acad. Sci. 1166, 156-166. http://dx.doi.org/10.1111/j.1749-6632.2009.04516.x.

Lopes, L.B., Guterres, A., Rozental, T., Carvalho de Oliveira, R., Mares-Guia, M., Fernandes, J., Figueredo, J., Anschau, I., de Jesus, S.V., Almeida, A.B.M., Cristina da Silva, V., Gomes de Melo Via, A., Bonvicino, C., D'Andrea, P., Barreira, J., Sampaio de Lemos, E., 2014. Rickettsia bellii, Rickettsia amblyommii, and Laguna Negra hantavirus in an Indian reserve in the Brazilian Amazon. Parasit. Vectors 7, 191. http://dx.doi. org/10.1186/1756-3305-7-191.

Martins, T.F., Onofrio, V.C., Barros-Battesti, D.M., Labruna, M.B., 2010. Nymphs of the genus Amblyomma (Acari: Ixodidae) of Brazil: descriptions, redescriptions, and identification key. Ticks Tick. Borne. Dis. 1, 75-99. http://dx.doi.org/10.1016/j. ttbdis.2010.03.002.

Martins, T.F., Venzal, J.M., Terassini, F.A., Costa, F.B., Marcili, A., Camargo, L.M.A., Barros-Battesti, D.M., Labruna, M.B., 2014. New tick records from the state of Rondônia, western Amazon, Brazil. Exp. Appl. Acarol. 62, 121-128.

Martins, T.F., Barbieri, A.R.M., Costa, F.B., Terassini, F.A., Camargo, L.M.A., Peterka, C.R.L., de C. Pacheco, R., Dias, R.A., Nunes, P.H., Marcili, A., Scofield, A., Campos, A.K., Horta, M.C., Guilloux, A.G.A., Benatti, H.R., Ramirez, D.G., Barros-Battesti, D.M., Labruna, M.B., 2016. Geographical distribution of Amblyomma cajennense (sensu lato) ticks (Parasitiformes: Ixodidae) in Brazil, with description of the nymph of A. cajennense (sensu stricto). Parasit. Vectors 9, 186. http://dx.doi.org/10.1186/ s13071-016-1460-2.

Martins, T.F., Luz, H.R., Faccini, J.L.H., Labruna, M.B., 2017. Life-cycle of Amblyomma oblongoguttatum (Acari: Ixodidae) under laboratory conditions. Exp. Appl. Acarol. 71, 415-424. http://dx.doi.org/10.1007/s10493-017-0135-9.

Melo, A.L.T., Martins, T.F., Horta, M.C., Moraes-Filho, J., Pacheco, R.C., Labruna, M.B., Aguiar, D.M., 2011. Seroprevalence and risk factors to Ehrlichia spp. and Rickettsia spp. in dogs from the Pantanal Region of Mato Grosso State, Brazil. Ticks Tick Borne Dis. 2, 213-218. http://dx.doi.org/10.1016/j.ttbdis.2011.09.007.

Nava, S., Beati, L., Labruna, M.B., Cáceres, A.G., Mangold, A.J., Guglielmone, A.A., 2014. Reassessment of the taxonomic status of Amblyomma cajennense (Fabricius, 1787) with the description of three new species, Amblyomma tonelliae n. sp., Amblyomma interandinum n. sp. and Amblyomma patinoi n. sp., and reinstatement of Amblyomma mixtum Koch, 1. Ticks Tick Borne Dis. 5, 252-276. http://dx.doi.org/10.1016/j. ttbdis. 2013.11.004.

Ogrzewalska, M., Pacheco, R.C., Uezu, A., Ferreira, F., Labruna, M.B., 2008. Ticks (Acari: Ixodidae) infesting wild birds in an Atlantic forest area in the state of São Paulo, Brazil, with isolation of rickettsia from the tick Amblyomma longirostre. J. Med. Entomol. 45, 770-774. http://dx.doi.org/10.1603/0022-2585(2008)45[770:Taiiwb] 2.0.Co;2.

Ogrzewalska, M., Uezu, A., Labruna, M.B., 2010. Ticks (Acari Ixodidae) infesting wild birds in the eastern Amazon, northern Brazil, with notes on rickettsial infection in ticks. Parasitol. Res. 106, 809-816.

Ogrzewalska, M., Uezu, A., Labruna, M.B., 2011. Ticks (Acari: Ixodidae) infesting wild birds in the Atlantic Forest in northeastern Brazil, with notes on rickettsial infection in ticks. Parasitol. Res. 108, 665-670. http://dx.doi.org/10.1007/s00436-0102111-8.

Oliveira, P.R., Borges, L.M.F., Lopes, C.M.L., Leite, R.C., 2000. Population dynamics of the free-living stages of Amblyomma cajennense (Fabricius, 1787) (Acari: Ixodidae) on pastures of Pedro Leopoldo, Minas Gerais State. Brazil. Vet. Parasitol. 92, 295-301. http://dx.doi.org/10.1016/S0304-4017(00)00322-8.

Oliveira, S.V., de Pereira, S.V.C., Amorim, M., Serra Freire, N.M., de Caldas, G.G.S., 2016a. Vigilância de ambientes da febre maculosa: explorando as áreas silenciosas do Brasil. Rev. Pan-Amaz Saude 55, 65-72. http://dx.doi.org/10.5123/S217662232016000300008.

Oliveira, S.V., Guimarães, J.N., Reckziegel, G.C., Neves, B.M.C., Araújo-Vilges, K.M., de Fonseca, L.X., Pinna, F.V., Pereira, S.V.C., de Caldas, E.P., Gazeta, G.S., GurgelGonçalves, R., 2016b. An update on the epidemiological situation of spotted fever in Brazil. J. Venom. Anim. Toxins Incl. Trop. Dis. 22, 22. http://dx.doi.org/10.1186/ s40409-016-0077-4.

Pacheco, R.C., Arzua, M., Nieri-Bastos, F.A., Moraes-Filho, J., Marcili, A., Richtzenhain, L.J., Barros-Battesti, D.M., Labruna, M.B., 2012. Rickettsial infection in ticks (Acari: Ixodidae) collected on birds in southern Brazil. J. Med. Entomol. 49, 710-716. http:// dx.doi.org/10.1603/ME11217.

Parola, P., Paddock, C.D., Raoult, D., 2005. Tick-borne rickettsioses around the world emerging diseases challenging old concepts. Clin. Microbiol. Rev. 18, 719-756. http://dx.doi.org/10.1128/CMR.18.4.

Raoult, D., Roux, V., 1997. Rickettsioses as paradigms of new or emerging infectious diseases. Clin. Microbiol. Rev. 10, 694-719.

Regnery, R.L., Spruill, C.L., Plikaytis, B.D., 1991. Genotypic identification of rickettsiae and estimation of intraspecies sequence divergence for portions of two rickettsial genes. J. Bacteriol. 173, 1576-1589. https://doi.org/0021-9193/91/051576-14\$02. $00 / 0$.

Sánchez-Montes, S., Ríos-Muñoz, C.A., Espinosa-Martínez, D.V., Guzmán-Cornejo, C., Berzunza-Cruz, M., Becker, I., 2016. First report of Candidatus Rickettsia amblyommii in west coast of Mexico. Ticks Tick Borne Dis. 7, 1139-1145. http://dx.doi.org/10. 1016/j.ttbdis.2016.08.007.

Sanger, F., Nicklen, S., Coulson, A.R., 1977. DNA sequencing with chain-terminating inhibitors. Proc. Natl. Acad. Sci. 74, 5463-5467. http://dx.doi.org/10.1073/pnas.74. 12.5463 .

Sangioni, L.A., Horta, M.C., Vianna, M.C.B., Gennari, S.M., Soares, R.M., Galvão, M.A.M., Schumaker, T.T.S., Ferreira, F., Vidotto, O., Labruna, M.B., 2005. Rickettsial infection in animals and Brazilian spotted fever endemicity. Emerg. Infect. Dis. 11 (2), 265-270.

Saraiva, D.G., Nieri-Bastos, F.A., Horta, M.C., Soares, H.S., Nicola, P.A., Pereira, L.C.M., Labruna, M.B., 2013. Rickettsia amblyommii Infecting Amblyomma auricularium Ticks in Pernambuco, Northeastern Brazil: isolation, transovarial transmission, and transstadial perpetuation. Vector-Borne Zoonotic Dis. 13, 615-618. http://dx.doi.org/10. 1089/vbz.2012.1223.

Soares, H.S., Barbieri, A.R.M., Martins, T.F., Minervino, A.H.H., de Lima, J.T.R., Marcili, A., Gennari, S.M., Labruna, M.B., 2015. Ticks and rickettsial infection in the wildlife of two regions of the Brazilian Amazon. Exp. Appl. Acarol. 65, 125-140. http://dx. doi.org/10.1007/s10493-014-9851-6.

Szabó, M.P.J., Pinter, A., Labruna, M.B., 2013. Ecology, biology and distribution of spotted-fever tick vectors in Brazil. Front. Cell. Infect. Microbiol. 3, 1-9. http://dx. doi.org/10.3389/fcimb.2013.00027.

Tamura, K., 1992. Estimation of the number of nucleotide substitutions when there are strong transition-transversion and G + C-content biases. Mol. Biol. Evol. 9, 678-687. http://dx.doi.org/10.1093/oxfordjournals.molbev.a040752.

Tarragona, E.L., Cicuttin, G.L., Mangold, A.J., Mastropaolo, M., Nazarena De Salvo, M., Nava, S., 2015. Rickettsia infection in Amblyomma tonelliae, a tick species from the Amblyomma cajennense complex. Ticks Tick Borne Dis. 6, 173-177. http://dx.doi.org/ 10.1016/j.ttbdis.2014.11.010.

Weinert, L.A., Werren, J.H., Aebi, A., Stone, G.N., Jiggins, F.M., 2009. Evolution and diversity of Rickettsia bacteria. BMC Biol. 7, 6. http://dx.doi.org/10.1186/17417007-7-6. 